\title{
GAMBARAN PENGGUNA AKSEPTOR SUNTIK 3 BULAN (DEPO PROGESTIN) DI BIDAN PRAKTEK MANDIRI ST. NILAWATI, S.ST PANGKEP
}

\author{
Fanni Astuti \\ Prodi D III Kebidanan, Sekolah Tinggi Ilmu Kesehatan Salewangang Maros \\ Email :fanniastuti04@gmail.com
}

\begin{abstract}
Abstrak
Pasangan usia subur di dunia hampir 380 juta pasangan menjalankan keluarga berencana (KB) dan 65-75 juta diantaranya di Negara berkembang menggunakan kontrasepsi hormonal seperti pil, suntik dan implant. Kontrasepsi hormonal yang digunakan dapat memiliki pengaruh positif dan negatif terhadap organ wanita. Pemakaian kontrasepsi hormonal terbanyak adalah kontrasepsi suntik yaitu sebesar $38 \%$ dan pill sebanyak $27,7 \%$. Adapun tujuan dari penelitian ini yaitu untuk mengetahui Gambaran Penggunaan Akseptor KB Suntik 3 Bulan berdasarkan umur ibu dan pengukuran tekanan darah ibu. Jenis data adalah data sekunder dengan melihat buku register di Bidan Praktek Mandiri ST. Nilawati Pangkep. Hasil penelitian didapatkan 564 pengguna alat kontrasepsi pada akseptor KB suntik 3 bulan (Depo Progestin) terdapat 263 (46,7\%), selain depo progestin sebanyak $301(53,3 \%)$. Berdasarkan umur ibu 20-35 tahun sebanyak $191(72,7)$ akseptor, pada umur > 35 tahun yaitu sebanyak $64(24,3 \%)$ akseptor dan terendah pada umur $<20$ tahun sebanyak $8(3,0 \%)$ akseptor. Berdasarkan pengukuran tekanan darah terdapat $263(100 \%)$ memiliki tekanan darah normal yang berarti bahwa keseluruhan responden berada dalam batasan normal tekanan darah.
\end{abstract}

Kata kunci : Suntik Depo Progestin, Umur Ibu, Pengukuran Tekanan Darah ibu

\begin{abstract}
Description Of 3-Months Injection Acceptor Users (Depo Progestin) In Midwife Practice Independently ST. Nilawati, S.ST Pangkep. The couples of childbearing age in the world, nearly 380 million couples run family planning (KB), and 65-75 million of them in developing countries use hormonal contraceptives such as pills, injections, and implants. Hormonal contraceptives used can have positive and negative effects on female organs. The highest use of hormonal contraceptives was injection contraception, which was $38 \%$ and the pill was $27.7 \%$. The purpose of this research is to know the description of the use of the 3-month injection family planning acceptors based on the mother's age and the measurement of the mother's blood pressure. The type of data is secondary data by looking at the register book at the Midwife Independent Practice ST. Nilawati Pangkep. The results showed that 564 users of contraceptives at 3 months injection contraceptive acceptors (Depo Progestin) were 263 (46.7\%), in addition to progestin depots as many as 301 (53.3\%). Based on the age of the mother 20-35 years, there were 191 (72.7) acceptors, at the age of $>35$ years there were 64 (24.3\%) acceptors and the lowest was at the age $<20$ years as many as 8 (3.0\%) acceptors. Based on blood pressure measurements, 263 (100\%) had normal blood pressure which means that all respondents are within the normal range of blood pressure.
\end{abstract}

Keywords: Depo Progestin Injection, Maternal Age, Measurement of Maternal Blood Pressure 


\section{Pendahuluan}

Menurut data World Health Organization (WHO), pasangan usia subur di dunia hampir 380 juta pasangan menjalankan keluarga berencana (KB) dan 65-75 juta diantaranya di Negara berkembang menggunakan kontrasepsi hormonal seperti pill, suntik dan implant. Kontrasepsi hormonal yang digunakan dapat memiliki pengaruh positif dan negatif terhadap organ wanita. Pemakaian kontrasepsi hormonal terbanyak adalah kontrasepsi suntik yaitu sebesar 38\% dan pill sebanyak 27,7\%. (Tendean Bella, 2017)

Indonesia menghadapi masalah dengan jumlah dan kualitas sumber daya manusia dengan kelahiran 5.000.000 per tahun. Untuk dapat mengangkat derajat kehidupan bangsa telah dilaksanakan secara bersamaan pembangunan ekonomi dan keluarga berencana yang merupakan sisi masing-masing mata uang. Bila gerakan keluarga berencana tidak dilakukan bersamaan dengan pembangunan ekonomi, dikhawatirkan hasil pembangunan tidak akan berarti. (Ida Ayu CM, 2010)

Pendapat Malthus yang mengemukakan bahwa pertumbuhan dan kemampuan menembangkan sumber daya alam laksana deret hitung, sedangkan pertumbuhan dan perkembangan manusia laksana deret ukur, sehingga pada suatu titik sumber daya alam tidak mampu menampung pertumbuhan manusia telah menjadi kenyataan. Berdasarkan pendapat demikian diharapkan setiap keluarga, memperhatikan dan merencanakan jumlah keluarga yang diinginkan. (Ida Ayu CM, 2010)

Keluarga sebagai unit terkecil kehidupan bangsa diharapkan menerima Norma Keluarga Kecil Bahagia dan Sejahtera (NKKBS) yang berorientasi pada "catur warga" atau zero population growth (pertumbuhan seimbang). Gerakan keluarga berencana nasional Indonesia telah berumur panjang (sejak 1970) dan masyarakat dunia menganggap Indonesia berhasil menurunkan angka kelahiran dengan bermakna. Masyarakat dapat menerima hampir semua metode medis teknis keluarga berencana yang direncanakan oleh pemerintah. (Ida Ayu CM, 2010)

Pemerintah meluncurkan gagasan baru, yaitu keluarga berencana mandiri artinya masyarakat memilih metode $\mathrm{KB}$ sendiri dengan biaya sendiri melalui KB lingkaran biru dan KB lingkaran emas dan mengarahkan pada pelayanan Metode Kontrasepsi Efektif (MKE) yang meliputi AKDR, suntik KB, Susuk KB dan kontap. (Ida Ayu CM, 2010)

Metode kontrasepsi yang paling banyak digunakan oleh peserta KB aktif di Indonesia adalah suntikan $(47,54 \%)$ dan terbanyak kedua adalah pil $(23,58 \%)$. Sedangkan metode kontrasepsi yang paling sedikit dipilih oleh peserta KB aktif yaitu Metoda Operasi Pria (MOP) sebanyak 0,69\%, kemudian kondom 
sebanyak 3,15\%. Sedangkan pada peserta KB baru, persentase metode kontrasepsi yang terbanyak digunakan yaitu suntikan sebesar 49,67\%. Metode terbanyak kedua yaitu pil, sebesar 25,14\%. Metode yang paling sedikit dipilih oleh para peserta KB baru adalah MOP sebanyak $0,21 \%$, kemudian Metode Operasi Wanita (MOW) sebanyak 1,50\%, dan kondom $(5,68 \%)$ (BKKBN, 2015).

Visi dan misi BKKBN mendorong akseptor Pasangan Usia Subur (PUS) untuk memakai jangka panjang. Dimana jangka panjang lebih menjamin wanita dalam mencegah kehamilan. Tetapi berdasarkan kenyataannya perempuan lebih memilih jangka menengah yaitu KB suntik 3 bulan.

Salah satu cara untuk mencegah kehamilan adalah dengan kontrasepsi suntik yang merupakan kontrasepsi hormonal. Salah satu jenis KB suntik berdaya kerja lama adalah DMPA (Depo Medroxyprogesterone Asetat) diberikan setiap 3 bulan sekali dengan dosis 150 mg. "Adapun keuntungan pemakaian alat kontrasepsi jarak menengah sebagai berikut : kerjanya yang efektif, pemakaiannya yang praktis, harganya relatif murah dan aman. (Abdul BS, 2010)

Suntik Depo Progestin menjadi KB yang paling banyak digunakan oleh ibu sehingga penulis tertarik untuk meneliti gambaran penggunaan kontrasepsi suntik Depo Progestin.

\section{Metode}

Jenis penelitian yang digunakan adalah survei dengan menggunakan metode deskriptif yaitu metode penelitian yang dilakukan dengan tujuan utama untuk membuat gambaran deskripsi tentang suatu keadaan

Populasi menurut Sugiyono (2018), juga dapat dikatakan sebagai wilayah generalisasi yang terdiri atas; objek/subjek yang mempunyai kualitas dan karakteristik tertentu yang ditetapkan oleh peneliti untuk dipelajari dan ditarik kesimpulannya. Populasi pada penelitian ini adalah seluruh jumlah akseptor aktif KB yang datanya tercatat lengkap dalam buku register hasil pelayanan $\mathrm{KB}$ di Bidan Praktik Mandiri Nilawati Pangkep sebanyak 564 Akseptor. Sugiyono (2010) menyebutkan bahwa sampel adalah bagian dari jumlah dan karakteristik yang dimiliki populasi. (Machfoedz Ircham, 2019). Sampel dalam penelitian ini adalah seluruh akseptor KB yang menggunakan alat kontrasepsi suntikan depo progestin yang datanya tercatat lengkap dalam buku register hasil pelayanan $\mathrm{KB}$ di Bidan Praktek Mandiri Nilawati Pangkep tahun 2019 sebanyak 263 akseptor.

Adapun cara pengambilan sampel dalam penelitian ini adalah dengan cara purposive sampling yaitu salah satu teknik pengambilan sampel yang sering digunakan dalam penelitian dengan pertimbangan tertentu. 
Teknik analisis data menggunakan formulasi, distribusi dan frekuensi. Data dianalisis dengan Analisis data yang dilakukan adalah analisis deskriptif dengan rumus $=$ $\frac{f}{n} \times 100 \%$. Pengolahan data dilakukan secara manual dalam bentuk tabel frekuensi dan presentasi dengan penjelasan tabel dalam naskah atau narasi.

\section{Hasil}

Hasil penelitian yang dilakukan di Bidan Praktek Mandiri Nilawati Kabupaten Pangkep, telah didapatkan 263 orang akseptor Kontrasepsi Suntik 3 bulan. Data yang diperoleh dari Buku Register Bidan Praktek Mandiri Nilawati selanjutnya diolah dan dan hasilnya disajikan tabel distribusi, frekuensi dan persentase dilengkapi dengan penjelasanpenjelasan dan secara keseluruhan dapat dilihat berikut ini.

\section{Hasil Gambaran Penggunaan Akseptor} Kontrasepsi Di Bidan Praktek Mandiri Nilawati Pangkep
Tabel 1. Hasil Gambaran Penggunaan Akseptor Kontrasepsi Di Bidan Praktek Mandiri Nilawati Pangkep

\begin{tabular}{clcc}
\hline No & $\begin{array}{l}\text { Akseptor } \\
\text { Kontrasepsi }\end{array}$ & Frekuensi & $\mathbf{( \% )}$ \\
\hline \multirow{2}{*}{1} & $\begin{array}{l}\text { Akseptor KB } \\
\text { Kontrasepsi } \\
\text { suntikan 3 } \\
\text { Bulan (Depo } \\
\text { Progestin) }\end{array}$ & 263 & $46,7 \%$ \\
\hline \multirow{2}{*}{2} & $\begin{array}{l}\text { Akseptor KB } \\
\text { selain Depo } \\
\text { Progestin }\end{array}$ & 301 & $53,3 \%$ \\
\hline & Jumlah & $\mathbf{5 6 4}$ & $\mathbf{1 0 0 \%}$ \\
\hline
\end{tabular}

Sumber data sekunder : Buku Register Bidan Praktek Mandir ST. Nilawati S.ST

2. Hasil Gambaran Penggunaan Suntik 3 bulan (Depo Progestin) Berdasarkan Umur

Tabel 2. Gambaran Penggunaan Suntik 3 bulan (Depo Progestin) Berdasarkan Umur Ibu di Bidan Praktek Mandiri ST. Nilawati S.ST

\begin{tabular}{llcc}
\hline No & Umur Ibu & Frekuensi & $(\mathbf{\%})$ \\
\hline $\mathbf{1}$ & $\begin{array}{l}\text { Umur }<20 \\
\text { tahun : } \\
\text { Menunda } \\
\text { kehamilan }\end{array}$ & 8 & $3,0 \%$ \\
\hline \multirow{2}{*}{$\begin{array}{l}\text { Umur 20-35 } \\
\text { tahun : } \\
\text { Menjarangkan } \\
\text { kehamilan }\end{array}$} & 191 & $72,7 \%$ \\
\hline & $\begin{array}{l}\text { Umur }>35 \\
\text { tahun : } \\
\text { Mengakhiri } \\
\text { kehamilan }\end{array}$ & 64 & $24,3 \%$ \\
\hline & Jumlah & $\mathbf{2 6 3}$ & $\mathbf{1 0 0 \%}$ \\
\hline
\end{tabular}

Sumber data sekunder : Buku Register Bidan Praktek Mandiri ST. Nilawati S.ST 
3. Hasil Gambaran penggunaan suntik 3 bulan (Depo Progestin) berdasarkan Tekanan Darah

Tabel 3. Gambaran penggunaan suntik 3 bulan (Depo Progestin) berdasarkan Tekanan Darah Ibu di Bidan Praktek Mandiri ST. Nilawati S.ST

\begin{tabular}{llcc}
\hline No & $\begin{array}{l}\text { Tekanan } \\
\text { Darah }(\text { Mmhg) }\end{array}$ & Frekuensi & (\%) \\
\hline $\mathbf{1}$ & $\begin{array}{l}\text { Tekanan Darah } \\
\text { rendah : } \\
<90 /<60\end{array}$ & - & - \\
\hline $\mathbf{2}$ & $\begin{array}{l}\text { Tekanan darah } \\
\text { normal : } 90- \\
120 / 60-80\end{array}$ & 263 & $100 \%$ \\
\hline $\mathbf{3}$ & $\begin{array}{l}\text { Tekanan darah } \\
\text { tinggi }\end{array}$ & - & - \\
\hline & Jumlah & $\mathbf{2 6 3}$ & $\mathbf{1 0 0 \%}$ \\
\hline
\end{tabular}

Sumber data sekunder : Buku Register Bidan Praktek Mandiri ST. Nilawati S.ST

\section{Pembahasan}

Setelah dilakukan pengolahan dan penyajian data beserta hasilnya, berikut ini dilakukan pembahasan hasil penelitian sesuai dengan variabel yang diteliti di Bidan Praktik Mandiri ST. Nilawati Pangkep.

\section{Hasil Gambaran Penggunaan Akseptor}

\section{Kontrasepsi}

Pada penelitian menunjukkan bahwa dari 564 pengguna alat kontrasepsi pada akseptor KB suntikan 3 bulan (Depo Progestin) terdapat 263 (46,7\%), selain depo Progestin sebanyak 301 (53,3\%).

\section{Hasil Gambaran Penggunaan Akseptor} Kontrasepsi Berdasarkan Umur Ibu
Berdasarkan tabel 2 diatas menunjukkan bahwa dari 263 akseptor KB suntikan (Depo Progestin) terbanyak pada umur 20-35 tahun yaitu sebanyak 191 (72,7 $\%$ ) akseptor, pada umur $>35$ tahun yaitu sebanyak 64 (24,3\%) akseptor dan terendah pada umur $<20$ tahun sebanyak $8(3,0 \%)$ akseptor.

Dalam hal ini penelitian yang didapat sejalan dengan teori dengan demikian umur akan menentukan dalam pemilihan jenis kontrasepsi yang digunakan bila ditinjau pola dasar penggunaan kontrasepsi yang rasional maka masa mencegah kehamilan (<20 tahun) dianjurkan untuk menggunakan kontrasepsi dengan urutan yang disarankan pil KB AKDR/IUD, dan kondom sedangkan pada masa menjarangkan kehamilan (20-30 tahun) dianjurkan untuk menggunakan kontrasepsi dengan urutan AKDR/IUD, pil KB, suntikan, implant/susuk, kondom dan kontap. Pada masa mengakhiri kehamilan (>30 tahun) dianjurkan untuk menggunakan kontrasepsi dengan urutan kontap, AKDR/ IUD, implant, suntik, pil KB, dan kondom.

\section{Hasil Gambaran Penggunaan Akseptor}

\section{Kontrasepsi Berdasarkan Tekanan darah Ibu}

Berdasarkan tabel 3 menunjukkan bahwa sebanyak 263 akseptor KB suntik semua memiliki tekanan darah normal 90- 
120/60-80 mmHg. Dalam hal ini penelitian sejalan dengan teori karena metode ini tidak dianjurkan kecuali metode lain tidak tersedia atau tidak dapat diterima jika seorang wanita menderita tekanan darah tinggi (180/110 mmHg). (Handayani, 2010) Indikasi suntik 3 bulan:

a. Usia reproduksi.

b. Nulipara dan yang telah memiliki anak.

c. Menghendaki kontrasepsi jangka panjang dan memiliki efektivitas tinggi.

d. Menyusui dan membutuhkan kontrasepsi yang sesuai.

e. Setelah abortus atau keguguran.

f. Telah banyak anak, tetapi belum menghendaki tubektomi.

g. Perokok.

h. Tekanan darah < 180/100 mmHg, dengan masalah pembekuan darah atau anemia bulan sabit.

i. Menggunakan obat untuk epilepsi (fenitoin dan barbiturat) atau obat tuberkulosis (rifampisin).

j. Tidak dapat memakai kontrasepsi yang mengandung estrogen.

k. Sering lupa menggunakan pil kontrasepsi.

1. Anemia defisiensi besi.

m. Mendekati usia menopause yang tidak mau atau tidak boleh menggunakan pil kontrasepsi kombinasi. (Handayani Asri, 2016)

\section{Kesimpulan}

Dari hasil penelitian yang menggunakan KB suntik Depo Progestin di Bidan Praktek Mandiri ST. Nilawati, S.ST maka dapat disimpulkan :

1. Dari hasil penelitian bahwa dari 564 pengguna alat kontrasepsi pada akseptor KB suntikan 3 bulan (Depo Progestin) terdapat 263 (46,7\%), selain depo Progestin sebanyak $301(53,3 \%)$.

2. Dari hasil penelitian menunjukkan bahwa dari 263 akseptor KB suntikan (Depo Progestin) terbanyak pada umur 20-35 tahun yaitu sebanyak $191 \quad(72,7 \quad \%)$ akseptor, pada umur >35 tahun yaitu sebanyak 64 (24,3\%) akseptor dan terendah pada umur $<20$ tahun sebanyak $8(3,0 \%)$ akseptor.

3. Dari hasil penelitian menunjukkan bahwa sebanyak 263 akseptor KB suntik memiliki tekanan darah normal 90-120/60-80 mmHg sebanyak 263 (100\%).

\section{Ucapan Terima Kasih}

Alhamdulillah puji syukur kehadirat Allah SWT atas berkat rahmat dan hidayahNya sehingga peneliti bisa menyelesaikan jurnal ini. Dalam kesempatan ini peneliti dengan tulus menyampaikan banyak terima kasih dan penghargaan setinggi-tingginya kepada institusi STIKes Salewangang Maros dan lahan penelitian atas kerjasama dalam 
selama proses meneliti, dan terkhusus kepada seluruh keluarga yang telah memberikan motivasi, doa dan pengorbanan materi maupun non-materi selama peneliti dalam proses pendidikan sampai selesai.

\section{Referensi}

As, N. (2017). Hubungan Penggunaan Kontrasepsi Hormonal Terhadap Kejadian Hipertensi Pada Wanita Usia Subur (WUS) di Puskesmas Kassi-Kassi Kota Makassar Tahun 2016 (Doctoral dissertation, UIN Alauddin Makassar)

Cahyani, S. D. (2017). Faktor-Faktor Yang Mempengaruhi Ibu Memilih Alat Kontrasepsi Suntik 3 Bulan Di Pt Starcam Apparel Indonesia Jepara (Doctoral dissertation, Universitas Muhammadiyah Semarang). Handayani, A. (2012). Gambaran Pengetahuan Ibu tentang Alat Kontrasepsi Suntik Depo Progestin di Puskesmas Mamajang Makassar Tahun 2012 (Doctoral dissertation, Universitas Islam Negeri Alauddin Makassar).

Imron. (2019). Apa Analisis Pengaruh Kualitas Produk Terhadap Kepuasan Konsumen Menggunakan Metode Kuantitatif Pada CV. Meubele Berkah Tangerang. Indonesian Journal on Software

Engineering. https://ejournal.bsi.ac.id/e jurnal/index.php/ijse/article/view/5861/ $\underline{3269}$.

Indriyani, Ratna Imas. (2016). Apa Asuhan Kebidanan Pada Akseptor KB Suntik 3 Bulan Terhadap Ny A Di Puskesmas Bojong Rawalumbu Bekasi Tahun 2016. https://www.slideshare.net/laurachiedar ddil/askeb-akseptor-kb-suntik-3-bulan.

Lontaa, Anita Kusmiyanti dan Robin Dompas. (2014). Apa Faktor-Faktor Yang Berhubungan Dengan Pemilihan Kontrasepsi Pasangan Usia Subur Di Puskesmas Damau Kabupaten Talaud. Jurnal Ilmiah Bidan. https://ejurnal.poltekkesmanado.ac.id/in dex.php/jidan/article/dowload/312/278.

Machfoedz, Ircham. (2019). Metodologi Penelitian Kuantitatif dan Kualitatif Bidang Kesehatan, Keperawatan, Kebidanan,

Kedokteran.Yogyakarta:Penerbit Fitramaya.

Mandang, Jenny, Freike Lumi, Iyam Manueke dan Naomy M.Tando. Apa Kesehatan Reproduksi dan Pelayanan Keluarga Berencana (KB). Bogor: In Media.

Manuaba, I. B. G. (2010). Ilmu kebidanan, penyakit kandungan dan keluarga berencana. Jakarta: EGC, 15, 157.

Mega dan hidayat Wijayanegara. (2017). Asuhan Kebidanan Keluarga 
Berencana. Jakarta: CV.Trans info Media.

Rizali, M. I., Ikhsan, M., \& Salmah, A. U. (2016). Faktor yang Berhubungan Dengan Pemilihan Metode Kontrasepsi Suntik di Kelurahan Mattoangin Kecamatan Mariso Kota Makassar. Media Kesehatan

Masyarakat Indonesia, 9(3), 176-183.

Rusmini dan dkk. (2017). Pelayanan KB dan Kesehatan Reproduksi. Jakarta: CV.Trans Info Media

Septianingrum, Yurike, Erika Martining Wardani danYanis Kartini. (2018). Apa Faktor-Faktor Yang Mempengaruhi Tingginya Akseptor Kb Suntik 3 Bulan. Jurnal Ners dan Kebidanan. http://creativecommons.org/licenses/by$\underline{\mathrm{sa} / 4.0 / .}$.

Tendean, Bella, Rina Kundre dan Rivelino S.H, (2017). Apa Hubungan Penggunaan Alat Kontrasepsi Suntik Depo Progesteron Asetat (DMPA) Dengan Tekanan Darah Pada Ibu Di Puskesmas Rontana Weru. E-journal Keperawatan.https://ejournal.unsrat.ac.i d/index.php/jkp/article/view/15819.

Wahyuni, E. S. (2017). Upaya Mencegah Efek Samping Penggunaan Kontrasepsi Depo Progestin Dengan Ekstrak Teh Hijau. Gaster, 15(1), 87-97.
Wati, L. R., \& Wulandari, D. T. (2017). Karakterstik Ibu (Usia, Paritas, Pendidikan, Pengalaman KB) Berhubungan dengan Pemilihan Metode Kontrasepsi. Journal of Issues in Midwifery, 1(2), 9-18. 